\title{
Effect of Water Retaining Polymer Application on the Productivity of Chickpea (Cicer arietinum) Under Dryland Agriculture
}

\author{
S. K. Dingre*, D. D. Pawar, M. G. Shinde and G. L. Tarte
}

Dept. of Irrigation Water Management, Post Graduate Institute, MPKV Rahuri Distt. Ahmadnagar (413 722), India

\section{Corresponding Author}

S. K. Dingre

e-mail: sachindingre@rediffmail.com

\author{
Article History \\ Manuscript No. AR1806 \\ Received in $8^{\text {th }}$ March, 2017 \\ Received in revised form $22^{\text {nd }}$ May, 2017 \\ Accepted in final form $7^{\text {th }}$ June, 2017
}

\begin{abstract}
A field experiment conducted during 2009-10 and 2010-11 to assess the effect of water retaining polymer on chickpea in light soils of western Maharashtra. The experiment comprised of 7.5, 10.0, 12.5, 15.017 .5 and $20 \mathrm{~kg} \mathrm{ha}^{-1}$ application of water retaining polymer before sowing and results were compared with conventional method in randomized block design with three replications. The superior chickpea yield ( $22.5 \mathrm{q} \mathrm{ha}^{-1}$ ) obtained when water retaining polymer applied @ $15 \mathrm{~kg} \mathrm{ha}^{-1}$ which was significantly on par with $12.5 \mathrm{~kg}$ ha-1 application $\left(21.2 \mathrm{q} \mathrm{ha}^{-1}\right)$. The conventional method of chickpea cultivation recorded significantly lowest yield $\left(14.1 \mathrm{q} \mathrm{ha}^{-1}\right)$. Pooled data indicated that water retaining polymer application increase the yield by 8 to $55 \%$. The $20 \mathrm{~kg} \mathrm{ha}^{-1}$ water retaining polymer used less quantity of water $(21.43 \mathrm{~cm})$ over conventional method $(27.35 \mathrm{~cm})$ with 10.3 to $27.6 \%$ water saving. Field water use efficiency improved considerably under application of $15 \mathrm{~kg} \mathrm{ha}^{-1}$ water retaining polymer $\left(10.1 \mathrm{~kg} \mathrm{ha}^{-1} \mathrm{~mm}^{-1}\right)$ among all treatments studied. The higher gross monetary returns (Rs. $67500 \mathrm{ha}^{-1}$ ), net monetary returns (₹ $28757 \mathrm{ha}^{-1}$ ) and B: C ratio (1.7) were also obtained with $15 \mathrm{~kg}^{-1}$ polymer application, however

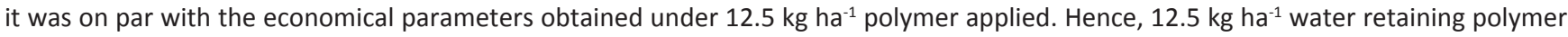
application before sowing was found suitable for chickpea cultivation in dry land areas of western India.
\end{abstract}

Keywords: Irrigation, water-retaining polymer, water use, moisture content

\section{Introduction}

Chickpea (Cicer arietinum L.) is one of the most important rabi crop and premier pulse of India. India grows chickpea on about $8.56 \mathrm{mha}$ area with $7.35 \mathrm{mt}$ production and 858 $\mathrm{kg} \mathrm{ha}^{-1}$ average productivity which represents $30 \%$ and $38 \%$ of the national pulse acreage and production, respectively (Tomar, 2010). In Maharashtra which lies in semi arid part of western India, cultivation of chickpea mostly done as a sole rain fed crop and it experiences moisture stress during crop growth resulting into low productivity. The productivity of chickpea in the state is low because it is mainly grown under receding moisture conditions with very limited or no irrigation. Chickpea responds well to irrigation and its yields can be increased upto $20-30 \%$ if supplemental irrigation is provided (Bhatia et al., 2006). With the advent of new cultivars responsive to irrigation and higher productivity, the area under chickpea cultivation (1.09 mha) is increasing at very fast rate in Maharashtra (Krishnamurthy and Sreeramula, 2007). However, the productivity of chickpea is still low in Maharashtra due to limited soil moisture available in rabi season, lack of improved agro techniques and minimum use of inputs (Jamdagni, 2007). Crop production potential in dryland region remains under exploited mainly due to constraint of effective water management. The limited availability of water therefore, necessitates the use of water management aids that can retain water for longer duration (Anupama et al., 2005; Singh et al., 2006).

The use of some water retaining polymer i.e. soil adjuvant may be an alternative for efficient management of water resources for dry land conditions. Small amount of these polymers can produce a significant conditioning effect in soil that lasts for a long time. Many investigations showed that synthetic polymers are effective means for improving structure and chemical properties of soil (Pradhan, 1993; Fullen et al., 1995; Brandsma et al., 1999). The soil polymer belongs to an acrylic series, polyacrylamide, polyocrylonitrile, polyacrylic acid and their polymers. There are also natural polymers such as cellulose, brown coal, peat and their conversion products but their efficiency is too low.

Use of cross linked hydrogels holds potential in this regard as these materials can alter the soil characteristics because of their ability to absorb water many times their weight and 
also retain for long duration, thereby reducing the water stress in plants (Menhi Lal et al., 1994; Bouranis et al., 1995; Minami et al., 2003). This becomes important especially in dry land soils where water stress negatively affects yield and yield components in chickpea (Rahman and Uddin, 2000). Water retaining polymer potentially gives a simple and effective way to retain moisture during non irrigation or stress period, improves soil aeration, water infiltration and nutrient availability (Helialia and Latey, 1998; Sokoowsk, et al., 2002). Thus, use of water retaining polymer is providing a new technology for dry land conditions and it is important to find out the effect of water retaining polymer on chickpea growth and yield behavior. Keeping above point in view, the present investigation was undertaken to ascertain the effect of water retaining polymer on water use efficiency, yield and yield attributes of chickpea.

\section{Materials and Methods}

\subsection{Site description}

The field experiment was conducted at research farm of Mahatma Phule Krishi Vidyapeeth, Rahuri, Ahmednagar district, Maharashtra during rabi seasons 2009-10 and 2010-11. Geographically, the experimental site is located at $19^{\circ} 24^{\prime} \mathrm{N}$ latitude and $74^{\circ} 39^{\prime} \mathrm{E}$ longitude at an altitude of $500 \mathrm{~m}$. Agro climatically the area falls under scarcity zone of Maharashtra with annual rainfall of $520 \mathrm{~mm}$, which is mostly concentrated during the monsoon months from June to September. The soil of the experimental field was $45 \mathrm{~cm}$ deep and was slightly alkaline in nature with $\mathrm{pH}$ of 8.37 and electrical conductivity of $0.39 \mathrm{dSm}^{-1}$. The soil texture was sandy clay loam having bulk density as $1.42 \mathrm{~g} \mathrm{~cm}^{-3}$ and organic carbon of $0.65 \%$, respectively. The soil was low in available N $(172 \mathrm{~kg}$ $\left.\mathrm{ha}^{-1}\right)$, and $\mathrm{P}\left(20.50 \mathrm{~kg} \mathrm{ha}^{-1}\right)$ and high in available $\mathrm{K}$ (302.4 $\left.\mathrm{kg} \mathrm{ha}^{-1}\right)$ content. The soil was having good drainage with infiltration rate $4.82 \mathrm{~cm} \mathrm{hr}^{-1}$. The moisture contents at field capacity, permanent wilting point and available soil moisture was 22.94, 9.66 and $13.28 \%$, respectively. The water table was more than $3 \mathrm{~m}$ below soil surface hence; there was no contribution to soil moisture from the underground water table.

\subsection{Treatments detail}

In present investigation, seven treatments comprise of different doses of water retaining polymer viz., 7.5, 10.0, $12.5,15.0,17.5$ and $20 \mathrm{~kg} \mathrm{ha}^{-1}$ application before sowing and conventional method were studied in randomized block design (RBD) with three replications. The water retaining polymer was applied in the soil and thoroughly mixed with soil before sowing. The sowing of chickpea (var 'Phule Digvijay') was done during November 2009 and 2010 at the spacing of $30 \times 10 \mathrm{~cm}^{2}$ by dibbling the seeds on both sides of ridges maintaining the row to row spacing. The recommended dose of fertilizer (30:60:30 Kg N: $\left.\mathrm{P}_{2} \mathrm{O}_{5}: \mathrm{K}_{2} \mathrm{O} \mathrm{ha} \mathrm{ha}^{-1}\right)$ was applied as basal dose for all the treatments. The growth as well as yield attributes of chick pea were measured.

\subsection{Irrigation}

One pre sowing irrigation $(5 \mathrm{~cm})$ and four subsequent irrigations were given at $50 \mathrm{~mm}$ cumulative pan evaporation (CPE). However, quantity of irrigation water to be applied was estimated as per the status of available soil moisture at root zone of respective treatment. Thus, quantity of water applied in each treatment was varied. One day before irrigation moisture content of each plot was measured by infrared moisture meter. The seasonal water requirement of crop was worked out. The net depth and time of irrigation were calculated by using following formulae (Michael, 2010).

$\mathrm{d}=\left(\mathrm{FC}-\mathrm{MC}_{\mathrm{bi}}\right) \times \mathrm{BD} \times \mathrm{D} / 100$

Where,

$\mathrm{d}=$ Net depth of irrigation $(\mathrm{cm})$

FC=Field capacity (\%)

$\mathrm{MC}_{\mathrm{bi}}=$ Moisture content one day before irrigation (\%)

$\mathrm{BD}=$ Bulk density of field $\left(\mathrm{g} \mathrm{cm}^{-3}\right)$

$\mathrm{D}=$ Root zone depth $(30 \mathrm{~cm})$

$\mathrm{V}=(\mathrm{d} \times \mathrm{A}) / 100$......

Where,

$\mathrm{V}=$ Volume of water $\left(\mathrm{m}^{3}\right)$

$\mathrm{d}=$ depth of irrigation $(\mathrm{cm})$

$A=$ Area of plot $\left(\mathrm{m}^{2}\right)$

$\mathrm{T}=(\mathrm{V} \times 1000) / \mathrm{q}$.

Where,

$\mathrm{T}=$ Time required for irrigation each plot ( $\mathrm{min}$.)

$\mathrm{V}=$ Volume of water $\left(\mathrm{m}^{3}\right)$

$\mathrm{q}=$ Discharge of stream (lpm)

The quantity of water to be applied per irrigation and seasonal water requirement of crop was worked out. The field water use efficiency (FWUE) was estimated as the ratio of crop yield, $\mathrm{Y}\left(\mathrm{kg} \mathrm{ha}^{-1}\right)$ and irrigation water applied (IW), in $\mathrm{mm}$ (Stanhill, 1986).

FWUE $=Y / I W$.

\section{Results and Discussion}

\subsection{Growth contributing characters}

The parameters regarding mean plant height, plant spread, number of branches plant ${ }^{-1}$ as influenced by different treatments at 30, 60 days after sowing (DAS) and at harvest are given in Table 1. It is indicated that application of $15 \mathrm{~kg}$ $\mathrm{ha}^{-1}$ water retaining polymer recorded higher value for the plant height at 30 DAS $(29.6 \mathrm{~cm}), 60$ DAS $(42.2 \mathrm{~cm})$ and at harvest $(44.3 \mathrm{~cm})$ as compared with different levels of water retaining polymer and conventional method. However, $12.5 \mathrm{~kg} \mathrm{ha}^{-1}$ polymer application was at par with $15 \mathrm{~kg} \mathrm{ha}^{-1}$ The conventional method of chickpea cultivation recorded significantly lowest value for the plant height of chickpea at 30 DAS $(27.6 \mathrm{~cm}), 60$ DAS $(37.2 \mathrm{~cm})$ and at harvest $(39.4 \mathrm{~cm})$ as compared with rest of the treatments.

The plant spread increased with increase in rate of water retaining polymer application up to $15 \mathrm{~kg} \mathrm{ha}^{-1}$. The plant 


\begin{tabular}{|c|c|c|c|c|c|c|c|c|c|c|}
\hline Treatments & $\mathrm{PH}$ & PS & NBH & NPP & $\begin{array}{l}\text { Weight } \\
\text { of pods } \\
\text { plant }^{-1}(\mathrm{~g})\end{array}$ & $\begin{array}{l}\text { Weight } \\
\text { of grains } \\
\text { plant }^{-1}(\mathrm{~g})\end{array}$ & $\begin{array}{c}\text { Test } \\
\text { weight } \\
\text { (g) }\end{array}$ & $\begin{array}{c}\text { Straw } \\
\text { yield } \\
\left(q \text { ha }^{-1}\right)\end{array}$ & $\begin{array}{c}\text { Grain } \\
\text { yield } \\
\left(q \text { ha }^{-1}\right)\end{array}$ & $\begin{array}{c}\text { Biological } \\
\text { yield } \\
\left(\mathrm{q} \mathrm{ha} \mathrm{h}^{-1}\right)\end{array}$ \\
\hline Polymer @ 7.5 kg ha-1 & 39.63 & 38.93 & 8.07 & 34.0 & 15.4 & 13.0 & 26.3 & 12.1 & 15.70 & 27.8 \\
\hline Polymer@10 kg ha-1 & 41.28 & 40.91 & 8.27 & 37.0 & 16.9 & 15.7 & 27.1 & 14.3 & 17.93 & 32.2 \\
\hline Polymer@12.5 kg ha-1 & 42.93 & 43.32 & 8.93 & 43.3 & 19.4 & 16.4 & 28.6 & 16.6 & 21.23 & 37.8 \\
\hline Polymer @ 15 kg ha-1 & 44.29 & 44.31 & 9.87 & 46.7 & 21.0 & 18.3 & 29.4 & 17.6 & 22.50 & 40.1 \\
\hline Polymer @ 17.5 kg ha-1 & 41.91 & 42.44 & 8.6 & 40.3 & 18.0 & 15.3 & 27.0 & 14.7 & 20.23 & 35.0 \\
\hline Polymer@ 20 kg ha-1 & 41.45 & 37.79 & 8 & 35.3 & 17.2 & 14.1 & 26.7 & 12.2 & 16.07 & 28.2 \\
\hline Control & 39.35 & 36.66 & 6.07 & 28.0 & 13.6 & 11.6 & 23.2 & 10.4 & 14.53 & 24.9 \\
\hline $\mathrm{CD}(p=0.05)$ & 1.37 & 1.28 & 1.17 & 3.4 & 1.7 & 2.1 & 3.2 & 2.2 & 2.19 & 3.7 \\
\hline
\end{tabular}

PH: Plant height $(\mathrm{cm})$ at harvest; PS: Plant spread $(\mathrm{cm})$ at harvest; NBH: No. of branches at harvest; NPP: No. of pods plant ${ }^{-1}$

spread was significantly higher at $15 \mathrm{~kg} \mathrm{ha}^{-1}$ as $33.2 \mathrm{~cm}, 41.6$ $\mathrm{cm}$ and $44.4 \mathrm{~cm}$ at 30,60 DAS and harvest, respectively as compared to other treatments. However, it was found at par with application of 12.5 and $17.5 \mathrm{~kg} \mathrm{ha}^{-1}$ at 30,60 DAS and harvest. Conventional method of chickpea cultivation recorded significantly lowest value for the plant spread of chickpea as $27.5 \mathrm{~cm}, 36.0 \mathrm{~cm}$ and $36.7 \mathrm{~cm}$ at 30,60 DAS and at harvest, respectively.

The number of branches plant ${ }^{-1}$ was also observed higher in application of $15 \mathrm{~kg} \mathrm{ha}^{-1}$ water retaining polymer at 30 DAS (4.2), 60 DAS (8.1) and at harvest (9.9) than application of different levels of water retaining polymer. However, it was at par with the application of $12.5 \mathrm{~kg} \mathrm{ha}^{-1}$ and $17.5 \mathrm{~kg} \mathrm{ha}^{-1}$ water retaining polymer. The favorable moisture availability resulted into favorable enhancement of growth attributes in polymer application of $15 \mathrm{~kg} \mathrm{ha}^{-1}$. The further increase in polymer application did not increased growth attributes of chick pea. The conventional method of chickpea cultivation recorded significantly lowest value for the number of branches plant ${ }^{-1}$ of chickpea as 3.5, 6.7 and 8.1 at 30, 60 DAS and harvest, respectively.

\subsection{Yield contributing characters}

The data indicated that the application of $15 \mathrm{~kg} \mathrm{ha}^{-1}$ recorded significantly highest value of number of pods and weight of pods plant ${ }^{-1}(46.7$ and $21 \mathrm{~g}$ ) as compared to other treatments (Table 1). The treatment application of $12.5 \mathrm{~kg} \mathrm{ha}^{-1}$ and 17.5 $\mathrm{kg} \mathrm{ha}^{-1}$ water retaining polymer application was at par with each other. When polymer application increases beyond $15 \mathrm{~kg}$ $\mathrm{ha}^{-1}$ it caused excess moisture in root zone which reduced the number of pods plant ${ }^{-1}$ of chickpea. The conventional method of chickpea cultivation recorded significantly lowest value of number of pods and weight of pods plant ${ }^{-1}$ (33.0 and $13.6 \mathrm{~g}$ ) as compared with rest of the treatments under investigation.

Similarly, weight of grains plant ${ }^{-1}$ (18.3 g) was also observed significantly higher when $15 \mathrm{~kg} \mathrm{ha}^{-1}$ water retaining polymer applied followed by $12.5 \mathrm{~kg} \mathrm{ha}^{-1}$ application. The test weight of chickpea (29.4 g) also showed similar trend however, it was at par with 12.5 and $17.5 \mathrm{~kg} \mathrm{ha}^{-1}$ polymer application. This was due to the increase in number of branches and number of pods. The weight of grains plant ${ }^{-1}$ and test weight recorded lowest value in conventional method (11.6 g and $23.2 \mathrm{~g}$ ).

\subsection{Yield}

The perusal of data regarding the total grain yield $\left(\mathrm{q} \mathrm{ha} \mathrm{a}^{-1}\right)$, straw yield $\left(\mathrm{q} \mathrm{ha}{ }^{-1}\right)$, biological yield $\left(\mathrm{q} \mathrm{ha}{ }^{-1}\right.$ ) and harvest index (\%) of chickpea showed increasing trend with increase in quantity of water retaining polymer up to a certain dose (Table 2). The application of $15 \mathrm{~kg} \mathrm{ha}^{-1}$ water retaining polymer recorded higher grain yield ( $\left.22.50 \mathrm{q} \mathrm{ha}^{-1}\right)$ as among different levels of water retaining polymer application. However, it was not significantly superior with $12.5 \mathrm{~kg} \mathrm{ha}^{-1}$ water retaining polymer application (21.23 q ha-1 ${ }^{-1}$. It showed that use of water retaining polymer beyond $15 \mathrm{~kg} \mathrm{ha}^{-1}$ resulted in excess moisture availability in root zone which caused adverse effect on yield of chickpea. The conventional method of chickpea cultivation recorded significantly lowest value (14.53 q ha-1).

Table 2: Effect of different treatments on the yield and water use efficiency of chickpea

\begin{tabular}{lcccc}
\hline Treatments & TWP & WUE & WS & HI \\
\hline Polymer @ $7.5 \mathrm{~kg} \mathrm{ha}^{-1}$ & 24.80 & 6.33 & 10.28 & 56.49 \\
Polymer @ 10 kg ha-1 & 24.10 & 7.44 & 13.49 & 56.81 \\
Polymer @ 12.5 kg ha-1 & 23.27 & 9.11 & 17.55 & 56.15 \\
Polymer @ 15 kg ha-1 & 22.17 & 10.14 & 23.38 & 56.09 \\
Polymer @ 17.5 kg ha-1 & 22.00 & 9.20 & 24.36 & 60.42 \\
Polymer @ 20 kg ha-1 & 21.43 & 7.51 & 27.60 & 55.29 \\
Control & 27.35 & 5.31 & -- & 58.26 \\
SEm \pm values & & & & \\
CD $(p=0.05)$ & -- & -- & -- & ---- \\
\hline
\end{tabular}

TWA: Total water applied (cm); WUE: Water use efficiency ( $\mathrm{kg} \mathrm{ha}^{-1} \mathrm{~mm}^{-1}$ ); WS: Water saving (\%); HI: Harvest index (\%) 
The straw and biological yield of chickpea were also showed similar trend as that of grain yield (Table 1 ). The minimum harvest index was obtained in $7.5 \mathrm{~kg} \mathrm{ha}^{-1}$ water retaining polymer( $56.49 \%)$ whereas it was high in $17.5 \mathrm{~kg} \mathrm{ha}^{-1}(60.42$ $\%)$. on the basis of these results it can be advisable that 12.5 $\mathrm{kg} \mathrm{ha}^{-1}$ water retaining polymer application is a suitable level for chickpea cultivated in light soil.

\subsection{Increase in yield}

The $15 \mathrm{~kg} \mathrm{ha}^{-1}$ polymer application produced $55 \%$ more yield as compared to conventional method whereas this increase in yield was upto $46.11 \%$ in $12.5 \mathrm{~kg} \mathrm{ha}^{-1}$ water retaining polymer (Table 2). The results showed that small expenditure of water retaining polymer could increase chickpea yield upto $55 \%$ over conventional method. The data also emphasized that an incremental application of 2.5 to $5 \mathrm{~kg}$ of water retaining polymer beyond $15 \mathrm{~kg} \mathrm{ha}^{-1}$ resulted in 15.7 to $44 \%$ decline in yield as against $15 \mathrm{~kg} \mathrm{ha}^{-1}$ application. Anupama et al. 2005 also reported a similar trend of result.

\subsection{Irrigation studies}

\subsubsection{Moisture content}

The average moisture content taken at 15 and $30 \mathrm{~cm}$ below the soil surface before every irrigation were found influenced under different levels of water retaining polymer application (Figure 1). This is revealed that polymer potentially retains the water in soil as moisture content was found in increasing trend with increase in levels of water retaining polymer. In $20 \mathrm{~kg} \mathrm{ha}^{-1}$ water retaining polymer application, moisture content was found near towards field capacity, which may caused excess moisture availability and ultimately resulted in reduction in yield.

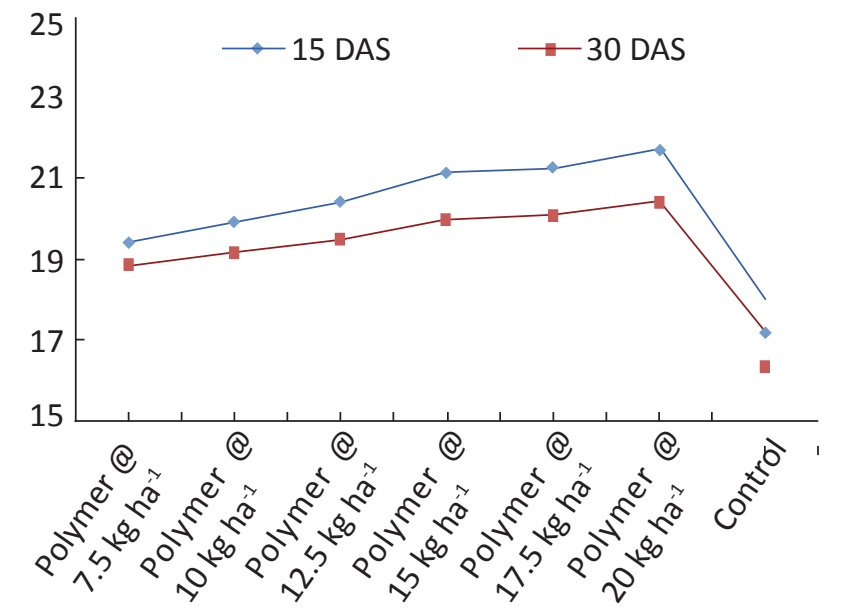

Figure 1: Average moisture content (\%) at every irrigation as influenced by different dose of water retaining polymer in chick pea root zone

\subsubsection{Water use}

The water use of chickpea crop was varied with different treatments of water retaining polymer application (Table 2 ). The water use decreased when dose of water retaining polymer increased. It revealed that water retaining polymer enhanced the water availability in root zone. The net depth of irrigation ( $\mathrm{cm}$ ) calculated using eq. (1) at every irrigation for different treatments is depicted in Figure 2. This is revealed that net depth of irrigation was found in decreasing trend with increase in levels of water retaining polymer. Efficient and low values of water use for chickpea were obtained in 15, 17.5 and $20 \mathrm{~kg} \mathrm{ha}^{-1}$ treatments as compared to conventional method i.e. $27.35 \mathrm{~cm}$. The application of $20 \mathrm{~kg} \mathrm{ha}^{-1}$ water retaining polymer recorded minimum water use $(21.43 \mathrm{~cm})$ and conventional method showed higher value $(27.35 \mathrm{~cm})$. As a result of that the water saving over conventional method was high (27.60\%) in $20 \mathrm{~kg} \mathrm{ha}^{-1}$ application followed by $17.5 \mathrm{~kg} \mathrm{ha}^{-1}(24.36 \%)$. The overall results showed that significant amount of water can be saved by using water retaining polymer especially in dry land condition.

\subsubsection{Water use efficiency}

Higher water use efficiency recorded in $15 \mathrm{~kg} \mathrm{ha}^{-1}$ water retaining polymer application of $\left(10.14 \mathrm{~kg} \mathrm{ha}^{-1} \mathrm{~mm}^{-1}\right)$ than rest of the treatments as higher yield was obtained in that treatment (Table 2). The next best treatment was $17.5 \mathrm{~kg}$ $\mathrm{ha}^{-1}$ application. The sufficient moisture in root zone of crop due to water retaining polymer caused favorable condition for growth and yield. Further, the water in root zone occupies more pore space due to decreasing of tension present in water. Therefore, the less water was used in treatment of 15 $\mathrm{kg} \mathrm{ha}^{-1}$ followed by $17.5 \mathrm{~kg} \mathrm{ha}^{-1}$. However, drastic reduction in water use efficiency was observed in $20 \mathrm{~kg} \mathrm{ha}^{-1}$ due to excess moisture available in soil root zone. The conventional method recorded lowest value (5.31 $\mathrm{kg} \mathrm{ha}^{-1} \mathrm{~mm}^{-1}$ ) due to low yield and higher water use.

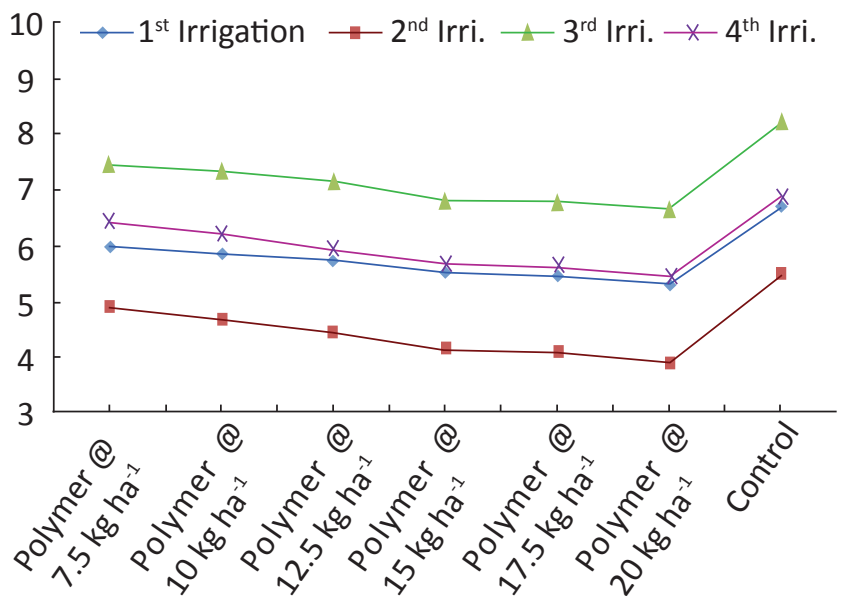

Figure 2: Net depth of irrigation $(\mathrm{cm})$ at every irrigation as influenced by different dose of water retaining polymer in chick pea root zone

\subsection{Economic studies}

\subsubsection{Cultivation cost and gross monetary returns}

Application of $20 \mathrm{~kg} \mathrm{ha}^{-1}$ water retaining polymer registered 
higher cost of cultivation ( $₹ 40,993$ ha $^{-1}$ ). The high market rates of water retaining polymer was the reason for higher cost of cultivation as against conventional method $\left(₹ 31,993 \mathrm{ha}^{-1}\right)$. The gross monetary returns ( $₹ 67,500 \mathrm{ha}^{-1}$ ) of chickpea cultivation were found significantly higher in $15 \mathrm{~kg} \mathrm{ha}^{-1}$ application which was at par with $12.5 \mathrm{~kg} \mathrm{ha}^{-1}$ and $17.5 \mathrm{~kg} \mathrm{ha}^{-1}$. Conventional method of chickpea cultivation recorded significantly lowest value (₹ 43,590 ha-1).

\subsubsection{Net returns and benefit:cost ratio}

The net monetary returns ( $₹ 28,757 \mathrm{ha}^{-1}$ ) from chickpea cultivation were also found significantly higher at application of $15 \mathrm{~kg} \mathrm{ha}^{-1}$ but it was at par with application of $12.5 \mathrm{~kg} \mathrm{ha}^{-1}$. Therefore, application of $12.5 \mathrm{~kg} \mathrm{ha}^{-1}$ water retaining polymer was considered suitable treatment for chickpea cultivation. Higher B:C ratio was estimated in application of $15 \mathrm{~kg} \mathrm{ha}^{-1}$ water retaining polymer (1.74) followed by $12.5 \mathrm{~kg} \mathrm{ha}^{-1}$ application (1.69). Use of $17.5 \mathrm{~kg} \mathrm{ha}^{-1}$ water retaining polymer recorded numerically minimum value (1.36) for the benefit: cost ratio as compared with rest of the treatments (Table 3 ).

Table 3: Effect of different treatments on the economic studies of chickpea

\begin{tabular}{lcccc}
\hline Treatments & CC & GB & NI & BCR \\
\hline Polymer @ 7.5 kg ha-1 & 35368 & 47100 & 11732 & 1.3 \\
Polymer @ 10 kg ha-1 & 36693 & 53790 & 17297 & 1.5 \\
Polymer @ 12.5 kg ha-1 & 37618 & 63690 & 26072 & 1.7 \\
Polymer @ 15 kg ha-1 & 38743 & 67500 & 28757 & 1.7 \\
Polymer @ 17.5 kg ha-1 & 39868 & 60690 & 20822 & 1.5 \\
Polymer @ 20 kg ha-1 & 40993 & 48210 & 7217 & 1.2 \\
Control & 31993 & 43590 & 11597 & 1.4 \\
\hline
\end{tabular}

CC: Cost of cultivation ( $₹$ ha $\left.^{-1}\right)$; GB: Gross benefits ( $\left(₹ \mathrm{ha}^{-1}\right)$;

$\mathrm{NI}$ : Net income (₹ ha-1); BCR: Benefit cost ratio

\section{Conclusion}

Water retaining polymer is seemed as an efficient water saving technology which either can save one or two irrigations or the amount of water per irrigation can be potentially reduced for rabi gram (cv. Digvijay), cultivated in sandy loam soil. It is concluded that the application of $12.5 \mathrm{~kg} \mathrm{ha}^{-1}$ water retaining polymer one time before sowing was found best practice to obtain better growth, improved yield with water saving and economically feasibility among the practices studied.

\section{References}

Anupama Rajesh, K., Jat, M.L., Parmar, B.S., 2005. Performance of a new Superabsorbant polymer on crop and water productivity of summer Mungbean. Journal of Water Management 13 (1), 1-5.

Bhatia, V.S., Singh, P., Wani, S.P., Kesava Rao, A.V.R., Srinivas, K., 2006. Yield Gap Analysis of Soybean, Groundnut,
Pigeonpea and Chickpea in India Using Simulation Modeling. Global Theme on Agroecosystems Report no. 31. International Crops Research Institute for the Semi-Arid Tropics (ICRISAT), 156.

Bouranis, D.L., Theodropoulos, A.G., Drossopoulos, J.B., 1995. Designing synthetic polymer as soil conditioners. Communication in Soil Science and Plant Analysis 26, 1455-1480.

Brandsma, R.T., Fullen, M.A., Hocking, T.J., 1999. Soil conditioner effect on soil structure and erosion. Journal of Soil and Water Conversion 54(2), 485-489.

Fullen, M.A., Tye, A.M., Cookcson, K.E., 1995. Effects of 'Agri$S C^{\prime}$ soil conditioner on soil structure and erodabilty. Agricultural Science 11(4), 185-186.

Helialia, A., Latey, J., 1988. So. Cationic Polymer Effects on Infiltration Rates with a Rainfall Simulator. Soil Science Society of American Journal 52, 247-250.

Jamdagni, G.M., 2007. Effect of irrigation on chickpea. Journal of Maharashtra Agricultural University 34 (3), 360-363.

Krishnamurthy, S.K., Sreeramula, E., 2007. Yield and yield attributes of bengalgram as influenced by time of sowing and number of irrigations during rabi season. Crop Research 33(1, 2 and 3), 65-67.

Menhi, L., Shikla, N.P., Lal, M., 1994. Efficiency of 'jalshakti' on graminaceous and leguminous forage crops. Indian Journal of Agronomy 39(1), 93-96.

Michael, A.M., 2010. Irrigation Theory \& Practice. (2 $\left.{ }^{\text {nd }} E d n.\right)$. Vikas Publishing House Pvt. Ltd, 523.

Minami, K., Bueno, S.C.S., Blat, S.F., Cuquel, F.I., 2003. Efficiency of soil conditioner on strawberry in Brazil. Acta Horticulturae 607, 169-173.

Pradhan, A.C., 1993. Effect of 'Jalshakti' on growth and yieid of finger millet (Eleusine coracana) and little millet (Panicum miliceum) at plateau region of Bihar. Indian Journal of Agronomy 38(4), 569-572.

Rahman, S.M.L., Uddin, A.S.M.M., 2000. Ecological adaptation of chickpea to water stress-2. Grain yield, harvest index, flowering and maturity studies. Legume Research 23(1), 1-8.

Singh, S., Malik, R.K., Yadav, A., Punia, S.S., 2006. Influence of irrigation, sulpher and seed inoculation on yield soil moisture studies on late sown chickpea (Cicer arientinum L.). Haryana Agricultural University Journal of Research 36, 23-29.

Sokoowsk, Z., Witkowaska, Walczak, B., 2002. Changes in water retention of different size soil aggregates caused by use of soil conditioner (Solacrol). Polish Journal of Soil Science 35(1), 1-10.

Stanhill, G., 1986. Water use efficiency. Advances in Agronomy $39,53-85$.

Tomar, R.K.S., 2010. Maximization of productivity for Chickpea (Cicer arietinum Linn.) through improved technologies in farmer's fields. Indian Journal of Natural Products and Resources 1(4), 515-517. 